\title{
BODY AND WRITING SOURCE AND SUPPORT OF ONE'S SINGULAR STYLE
}

Why do undergraduate students tend to transform their academic texts in smoke screens that hide the inscription of their singularity? In order to answer this question, we have studied manuscripts (marked by lack of originality, an excess of quotes or, even, a self-declaration of his own incapacity to write) representing various stages in the development of written works. We have searched to be supported by psychoanalysis aiming to understand the correlation between the transformations in the manner each student handles his drives with the possibility to construct the conditions to express marks of authorship in their reports of research. We have done so in order to read the path towards an integration of the body of two students. More specifically, we searched to know if there was any correlation between the moving from a passive position to an active position and the improvement of the versions. We could realize one could easily get manage his drives when he allows himself to get external help. Therefore, the mentor could act threefold. First, he could help his student to accept the separation of the relative consistence of his imaginary body to gain more "voices". Secondly, he could act as a "secretary" of the different voices, in order to help the writer to put them in a correct hierarchy. Finally, he should go out of the scene when he discovers that the student has gained autonomy.

Key words: Writing, Style, Psychoanalysis, Body, Authorship

\section{Introduction}

Ecrire, c'est produire un objet, une trace matérielle, c'est-à-dire donner à voir cet objet, à soi-même ou aux autres. Cette production « hors de soi » nécessite une prise de distance par rapport aux informations et contenus écrits, et, dans le même temps et le même mouvement, contribue à cette prise de distance. [...] De cet point de vue, l'écriture est bien un lieu d'organisation et de réorganisation, de mobilisation et construction de connaissances sur elle-même et sur le monde. (BARRÉ DE MINIAC, 2000, p.33). 
When one reads texts published by the press, he can be convinced that humans have conquered an amazing new society. In this brave new world, all minorities have their places, nobody suffers from prejudice, and the freedom of expression is no more a dream. Therefore, it is at least surprising to find out that this idyllic world is not reflected in academic texts written by undergraduate students.

If, at least hypothetically, nowadays it is possible for everyone to construct a point of view, why do undergraduate students tend to transform their academic texts in smoke screens that hide the inscription of their singularity? Why are the majority of the texts marked by lack of originality, an excess of quotes or, even, substituted by the author's declaration of his incapacity to write?

In order to answer these questions, we have studied manuscripts representing various stages in the development of written works. Our general aim was to understand the achievement of overcoming seemingly unexplainable writing difficulties (the ones that are not due to ignorance or seems not to be effect of lack of attention). The specific one was to find out evidence that the author has managed to deal with anguish caused by the strangeness of the arousal of the new idea. For us, this conquest is possible only for those people who can psychologically accept the uniqueness of his body and, therefore, can learn how to administrate his drives.

In our preliminary analysis, we have found out a very curious phenomenon: the absence of singularity seems not to be correlated to the lack of unprecedented ideas. On the contrary. It is when the student is faced with the difficulties if sharing an innovative thought that he either gives writing up or is not able to write an understandable text.

We think this is a big problem in teacher training. Consequently, we have decided to discover how students organize themselves in order to share the results of the research they have to make during their course. More specifically, we want to analyze in which measure they act to express communicative intentions that are strongly subjective. (POTTIER, 2000).

To do so, we studied the linguistic-discursive elements of manuscripts representing the various stages in the development of written works to highlight the different ways undergraduate students and teachers can (or cannot) back up the inscription of his singularity in academic productions. We have inscribed our work in a research tradition in which the analytic regard implies choices: 
[... ] celles de la production sur le produit, de l'écriture sur l'écrit, de la textualisation sur le texte, du multiple sur l'unique, du possible sur le fini, du virtuel sur le ne varietur, du dynamique sur le statique, de l'opération sur l'opus, de la genèse sur la structure, de l'énonciation sur l'énoncé, de la force de la scription sur la forme de l'imprimé. (GRÉSILLON, 1994, p.21).

By comparing the development of different manuscripts, we have chosen to examine how the researcher who is being formed is (or is not) able to read his own text. To the extent that he can remain distant from the information and contents he needs to compose his texts, as Barré de Miniac (2000) puts it, he will be able to work on his own linguistic and textual expression.

The researchers of our research group (GEPPEP) created our database in 2009. It consists of 1813 manuscripts, comprising letters, memories, short stories, research reports, dissertations and theses written by ten different people between 2004 and 2012. Its total amount is 29276 pages. Riolfi and Andrade (2009) have already explained the procedures of its composition, organization and initial analysis.

Our first motivation to compare versions of manuscripts was pragmatic. Observing how post graduate students construct their written path, we could notice that students tend to hide themselves in a kind of smoke screen: lack of originality, an excess of quotes or, even, a self-declaration of his own incapacity to write are presented where one would expect to have at least an average text.

While examining the corpus, the following phenomena has put us in track of the managing of the singular traits: 1) The ones which can enlighten someone's need to deal with his unconscious; and 2) The occurrences that point out the person's need to invent a solution to which represents an inner division of him. We needed to study the versions because we have seen that it is both the problem of subjective division and the creation of its solution: a) Do not always appear in the public version of the text; b) Offer (or do not offer) the writer an opportunity to unify his thought.

Supported by psychoanalysis, we understand the body as the necessary path to the achievement of singularity in writing. For us, one's body can be presented in writing both in a positive and in a negative way. If 
someone can administrate the otherness of one's body represent to everybody, he can feel it as a source of happiness to be alive.

On the other hand, if he cannot integrate this oddness, his anguish can give origin to a curious phenomenon. When he has high moral standards, he tends to judge himself badly when he is too excited or aroused with his task. He cannot join "work" and "joy" and, therefore, ends up as a victim of a vicious circle: crime and punishment. Another possibility is that he gets so upset with the possibility to disappoint his reader that he forgets the limits of physical existence.

\section{Theoretical References}

Even good high school students have a difficult time in learning how to write when they start college education. Chabanne e Bucheton (2002) point out that this moment demands an epistemological rupture: from a utilization of the written code towards meaning production, the person needs to learn how to validate it in a particular area of expertise.

In order to succeed, the students will need, among many other actions, to learn to maintain distance from their own production. This maintenance is not easy for everybody because it puts the identity of the writer into question. Deschepper e Thyrion (2008) for instance, have shown that, when somebody starts his college education, it is necessary to face the annoyances that occur in the conceptions and representations that he possesses of what writing is and, besides, in his perceptions of himself. The way he is able to embrace his own body is part of the package.

Having said that, we can declare that we agree with psychoanalysis according to which there is a strong correlation between the achievement of singularity and the management of the drive. The word "drive" is used to refer to: a) The exciting processes that are originated at the erogenous zones of the body; b) The phenomena that are, at the same time, concerning to the body and to the mind; and c) The psychic representative of endless, non-stop exciting processes of the body (FREUD, 1905).

Freud came up with this concept to show the differences between animal's instinct, which are not mediated by culture and human sexuality, which is traversed by human language, always opaque, creative and equivoque. For psychoanalysis, between the human being and the so-called empiric reality, there is the sexuality, which is always lived by our drives. 
According to Lacan (1964), the "drive" refers to: 1) The psychic representative of endless, non-stop exciting processes that erogenous zones of the body originate; 2) A process modeled from the word. The desire to get satisfaction manifests itself in the form of a will to speak; and 3) A blind action the person fells impelled to execute to satisfy himself when he cannot recognize or give course to his desires.

Targeting to obtain satisfaction, the drive can impose different amounts of pressure (driving force or work requirement) over the person. It is originated on a physical source, a body part on which occurs the arousal represented in mind, that is: the eye; the ear; the mouth and the anus. Most usually, in order to get satisfaction, the person recurs to different objects, all of them metaphoric substitutes of the ones that are related to physiological processes: the look; the voice; the breast and the stools.

Lacan (1964) stresses that the most important thing to understand about the concept of drive is that, under the strong pressure of the drive, the person can identify himself with the object that torments him, and therefore, can put himself in the object's place in order to be satisfied. He can adopt the following subjective positions: make himself being seen; make himself being heard; make himself being suck and make himself being excreted.

For those who are pursuing education, we can say that the drive can be worked the following way. The drive's object are the objects of study that the person elects as the preferred ones. Its source are the parts of the body that are more closely involved in their work, such as hands and eyes. The drive's target is to provide the student with the intellectual satisfaction that results from the elaboration about the subject being studied. Its pressure is the amount of energy the person feels like investing in the study.

Moreover, its subjective position refers to the way the person deals with his relationships with the other people. Quarrelsome and rebel students, for instance, sometimes get inner satisfaction when expelled from the institution as the stools is excreted from the body.

When we say that the emergence of a style results in the management of the singular body traits, we are implying that in order to succeed as a creative writer, a person has to abdicate the satisfaction obtained from the condition of being an object and has to accept responsibility for his authorship. Next, we are going to see how this process developed on the story of two students. We will call the female one Bridget and the male one Expedito. 


\section{Bridget and Expedito: the influence of the body in the writing process}

When students who cannot manage their drives try to write their academic texts odd things seem to happen. Especially, as the versions of the texts progresses, the text does not get better as it is expected. For the sake of clarity, in what follows we will analyze the discursive and linguistic elements from his text, comparing parts of students' work between the trials.

We will start with some fragments of Bridget's production. Picture 1, which follows, can provide an example of what we are calling "odd things":

$$
\begin{array}{ll}
\text { Original fragment in Portuguese } & \text { English } \\
& \text { Version }
\end{array}
$$

Nessa reprodução da capa da edição de novembro de 2002 é possivel observar uma fotografia da professora que venceu o concurso no ano em questão. Olhando atentamente, percebemos que ela foi fotografada em traje de gala, segurando o troféu que ganhou. Logo abaixo, lê-se: "A professora do ano."

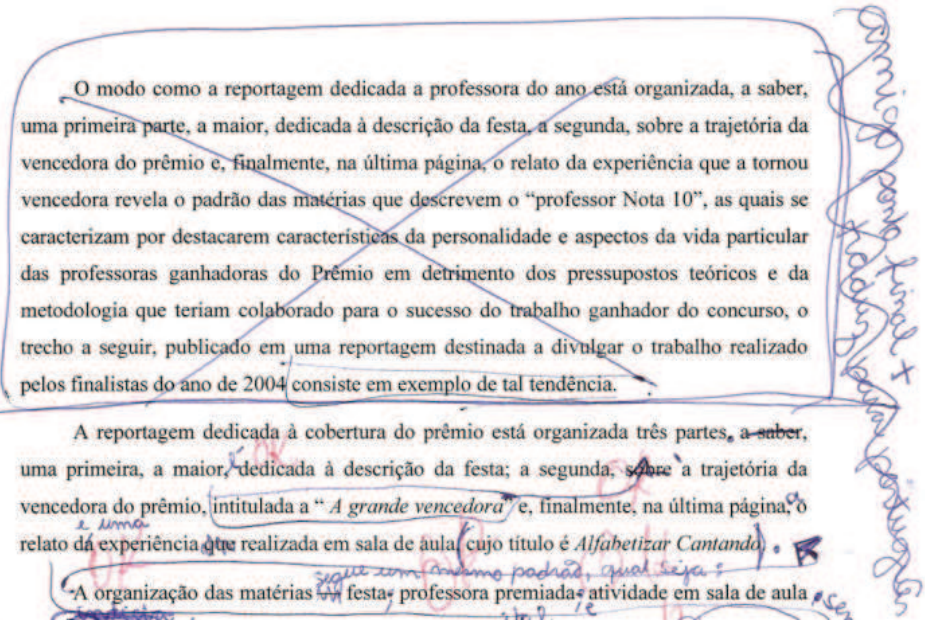

Picture 1: Mentor's remark in text written a year and six months after starting the research by a postgraduate student, a 26-year-old teacher, researcher in preparation 
Analyzing the fragment reproduced in picture 1, we can see that the mentor rejected one paragraph entirely (the second one) and criticized another one (the first one). It is important to point out that both were produced after four previous essays.

Even if we do not accept the mentor's judgment, it is at least curious that a text that has been written so many times causes this type of reaction to the reader. Common sense expects a text to get better when one works on it. An experienced reader in judging texts did not legitimate this improvement.

Having noticed that, we can make two hypothesis. The first one is that, by being lazy or having cognitive troubles, the student does not want to or cannot perform the written task he has been asked to do. The second is that the student who is not able to progress as time goes by is not necessarily indolent or little intelligent.

We bet on the second one. As our title puts it, his body can jeopardize him. He still does not understand that his body can be, at the same time, the source and pillar of his singular style. Therefore, sometimes he needs some help from the outside to administrate it. It is the case of Bridget.

In the middle of the versions of the texts that she has written in order to produce her dissertation, we have found something that made us suspect that, for her, one's body was somehow evident to everybody around her. We are referring to one small note that she has written to herself after the eighteenth month of the beginning of her postgraduate studies. Picture 2 reproduces it.

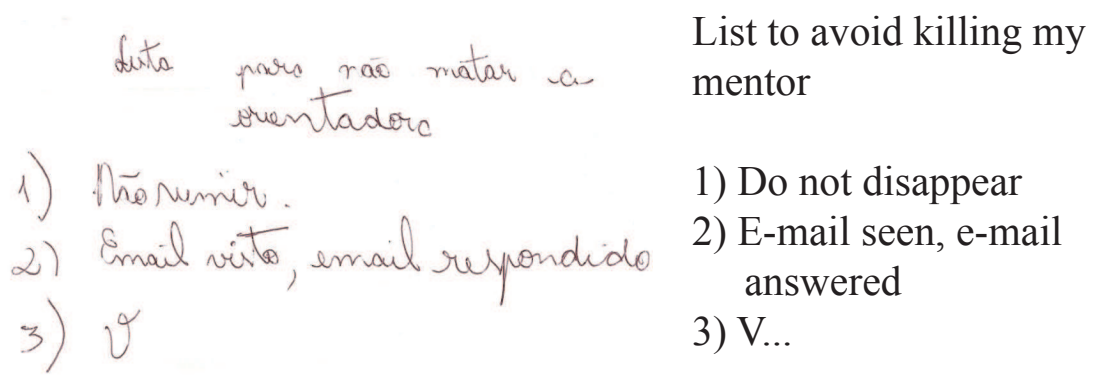

Picture 2: Informal text of the student

What does the student do with that note: she forbids herself to do two things: to vanish and to let her mentor emails without an answer. In other words, she is giving herself an order to let her body be. Why did she do it? Most probably because, in the beginning, while doing essays to produce 
her master's dissertation, her research mentor got angry with some of her actions (disappearing from the university and not answering e-mails) and told her something exaggerated along the lines of: You will kill me if you continue acting that way.

While writing the note, this student administrated not only many voices but also, properly speaking, three subjective positions:

1. The reproduction of the voice of her research mentor, who gives the commands that are reproduced in the note;

2. The incorporation of the ideal reader (herself), the student who could not control the behavior that prevented her from succeeding her task; and

3. The presence of the instance by which, having noticed that was making a mistake, decided to write to herself.

The analysis of Bridget's corpus permitted us to realize that she had to write to herself three times again and, afterwards, did not have more problems. She was able to see and be seen and, consequently, to write and to show her written texts.

We could still ask ourselves where the body is in this case. It is important to point out that, when the student has written the sentence "List to avoid killing my mentor", she occupies the place of her own mentor. To do so, she had to make her body be the support of a character that overcomes it. In order to obey herself and "do not disappear" she would have to bare her own body being alive.

So, to fullfill her command, besides going to the University and telling her mentor how her research is doing, she would have to assume the possession of her body. This means not killing it symbolicaly by its physical desapearence. Nevertheless, it is not that easy. When she writes "Seen e-mail, answered e-mail", she does not mention the necessary effort to compose an anwer. "To see" is not a synonim of "to read". One can fullfill the first action only partially capturing the text with his look. Besides, between "seen" and "answer" the time to write elapses. Concluding: She did try hard to sustain the presence of her body while writing, but was not completely succesfull.

While writing, she does not know what to do with her own body. She is not an isolated case. The same thing happened with Expedito, which case was previously studied by Spinelli (2012). She was the one who gathered and organized his corpus and shared the main facts occurred during his stay in the University. According to her, he had two different female 
mentors. The first one (M1) accompanied him for two years and a half. The second (M2), for six months.

When M1supervised his work, he failed in his post graduations examinations. M1 gave up on being his mentor and formally requested that the University provided the student another mentor. As the bureaucratic procedures to change mentors take a long time, he stayed alone for three months. As he only had this exact time to try to take his exams again, it was urgent to find a new mentor, because it is forbidden to try to take new exams alone.

When he finally was acquainted with M2 and started to work with her, he had already lost all the deadlines and, therefore, the University cancelled his inscription twenty days after he thought his situation had been solved. Both decided to continue working and Expedito regained his place by means of an administrative procedure. Very happy, he wrote a new dissertation and, this time, was successful in his examination.

The two trials generated 660 pages. During the period he failed, he produced 4 manuscripts, totalizing 448 pages: one theory review and three full dissertation versions, which included cover, summary, abstract, bibliography and annexes, these texts have just a few comments made by M1. During the period he succeeded, he produced 10 manuscripts, totalizing 214 pages: different versions of chapters, an average of three versions per chapter, which were commented by M2 and members of a study group coordinated by M2.

By looking on these numbers, we can observe how different the procedures that resulted in both texts were opposite. If we compare the two versions having the influence of the drive on the mind, we can see the way Expedito dealt with it was very different. When he led his first trial, he satisfied his drives through a self-obtained manner. This tendency can be seen, for instance, when we see that he avoided showing the versions of his text to M1.

When Expedito did not let his mentor accompany his writing process, he protected his ideal self-identity: the one of a good student who wrote many pages. By doing that, Expedito hid his body behind a generic text. The consequence of this choice is that he did not produce something that could be good enough to keep his body in the master program.

On the other hand, during the second trial, he needed the help from other people to satisfy his drive. Therefore, instead of hiding his texts, he submitted them to the supervisor more often. From a passive position of someone who was happy with the imaginary he had of himself, he could 
evolve to an active one, of somebody who was happy to suffer the influence of M2 and work after that.

We will start by analyzing Expedito's presentation of his research problem. In Brazil, one would expect the presentation of the research problem to be a part of the dissertation in which something new is added. According to Riolfi (1999), every research problem is a chance for the researcher to express his singular traits. In other words, one's body can be presented in its text by the contribution, which the writer pretends to offer to scientific community.

In Expedito's case, this contribution is more visible in the second tentative. In the first one, he presented generic questions instead of working to produce something that could be called as legitimately "his". Under M2's supervision he, at least, tried to compose a question that was clearly linked to the specific object he aimed to comprehend. In order to examine this difference closer, we will present both research problems in frame 1.

Expedito's presentation of the research problem in his first dissertation

[...] deve-se ou não se deve alfabe- One should or not be alphabetized tizar no Ensino Infantil? O que se during infantile education? What is entende por alfabetização no Ensi- understood by alphabetization in inno Infantil? Qual é o papel do Ensi- fantile education? What is the role no Infantil nos processos de ensino of infantile education in the process aprendizagem da leitura e da escrita? of reading and writing acquiring?

Original data in Portuguese English Version

Expedito's presentation of research problem in his second dissertation

[...] analisar os modos por meio dos To analyze the mode by which the quais as diversas teorias concernen- several theories concerned to infantes à Educação Infantil são repre- tile education are represented in the sentadas no periódico $[. .$.$] \quad magazine [. .$.

Original data in Portuguese English version

Frame 1: Expedito's research problem in both dissertations

If we look at frame 1, we can notice linguistic marks of the presence or absence of the writer's body during the composition of the text. Start- 
ing with Expedito's first trial, we can see that instead of making an effort to construct a research problem, he just presented three separate questions that could be asked by any layperson.

Although they could, with some good will from the reader, look like research questions by their formal aspects, they show no work that could reveal implication of the researcher body. We could say that what he tries to accomplish what he imagines to be the expectations of M1. As he does not really know them, he is not even able to choose one question, so, paraphrasing Barzotto (2013), he remains entangled in his reading material as someone who has fallen into a river and does not manage to reach its margins.

We cannot encounter linguistic marks that point to the subjective division. Instead, the writer remains attached to the truth of an outside voice, which he seems willful to embody. Expedito shows that he puts himself in a place of someone who could dictate universal truth.

By the use of the modal verb "dever" ("must") he expresses his preference for deontic modality (Pottier, 1992). Having made that choice, he left no space to a possible reader to disagree with the content of the statement without disagreeing with the author himself. Therefore, Expedito writes in a way that leaves the discussion is on a personal level. This is a strong evidence that he was not able to deal with his own drives.

As Barzotto (2010) has shown in his analyzes of texts dedicated to study Portuguese teaching methodologies, the use of this kind of modalities can point to a specific image of academic writing. Expedito is more concerned with what one must say about the knowledge than with its production.

Having said that, we can now examine the fragment of the second dissertation. There, Expedito presents the research problem as a general aim. Its presentation was previously well prepared. It appeared in the page number six, after: a) a presentation of the magazine he referred to; b) an overview of the literature comprising research about magazines; c) a critique of the previous works who dedicated themselves to the same magazine he was then taking as his object of study.

When one reads the fragment, it is possible to infer that the writer administrated at least three instances. In order to accomplish this aim, he had to articulate a) the one who announces what is the objective of the research $b$ ) the one who allows to pursuit this objective considering the object he has chosen and c) the theory used in order to accomplish the aim. 
What is, then, that changed so much when Expedito was expelled from the institution (made himself be excreted) and when he endured there long enough to produce a written dissertation (to be excreted as an object in its acceptable form in our culture)?

Examining this second fragment, we can dare to say that he learned that in order to survive inside the University it was necessary to do much more than to reproduce what he thought would be the truth. In order to juxtapose them would not be enough to make a textual body. This is the lesson he seemed to have learned in his second trial. Between the act of questioning and that of composing an answer, he would have put his body to work.

If we consider his results, we can observe a considerable transformation: Expedito switched from a passive position (in which the satisfaction of the drive was obtained through an object) to an active position (in which the satisfaction of the drive was obtained within a subjective position. The second solution had a complementary advantage: he could establish a worthwhile relationship with others and sustain them. The number of different peers who read his texts while he was working with M2 revealed this, for instance.

The presentation and analysis of data reveals some switch. In the first dissertation, he avoided the contact with the research data and was not able to produce a personal interpretation of it. He just wrote about his corpus in his third version of the dissertation, which is the last manuscript he wrote when he had M1 as a mentor. Even there, Expedito mentioned it in the abstract's last line and forgot it for 61 pages.

On page 62, its presentation consisted in some information about the interviews used as research data followed by transcripts of the selected fragments. There was no effort to do the analysis. These choices are coherent with the position of someone who puts himself in a place of an object and, therefore, maintains a self-obtained satisfaction.

In the second dissertation, differently, we could observe that Expedito mentioned the data in the abstract's first line and presented it during the entire introduction chapter. He made an effort to give it a visual concreteness by inserting tables, graphics and textual extracts.

The effort he made to understand his data could be seen by his choice of presenting analysis throughout the dissertation. In fact, he used the examination of his corpus as part of the argumentative strategy in his dissertation, therefore, exposing not only himself, but also, also, his journey towards his object of wisdom. 


\section{Conclusions: implications to the teaching of academic writing}

By comparing different versions of texts in order to find out how teachers improve their academic writing, we have shown that to write is an important part in the processes of teacher education when the management of the singular body traits exists. In order to succeed in writing, the person needs to think up a solution to the object that arouses an inner division.

From a passive position, typical of a person who cannot administrate his drives, the person needs to construct an active position, responsible for the acquisition of the kind of authorship that is related with the integration of the body. When the student does not give the necessary attention to his corporal phenomena, he will tend to experience: desegregation; difficulty to fulfill his own purpose; difficulty to convey meaning; difficulty to write more clear versions while revising and difficulty to surpass common sense.

If a supervisor wants to help his student to administrate the strangeness of the body, he should not reinforce bad moral judgment the student makes of himself. Writing a bad text version does not mean that a person who writes is no better than something that could be excreted. The supervisor could also fulfill the following actions:

a) Help the writer to gain more "voices" by accepting the separation of the relative consistence of the body and the mutability of his forms of expression;

b) Act as a "secretary" of the different voices, in order to help the writer to put them in a correct hierarchy; and

c) Go out of the scene when he discovers that the student has gained autonomy.

The research has shown that, when one can integrate his drives along with his work, he has more intellectual energy than he would have if he had not done it. Being able to put effort in his task, he will be capable to learn how to administrate different voices to compose his text.

Therefore, as Certeau (1994) puts it, it will be the metaphor of his body and will not be anymore an anonymous voice. The theory, the data, the supervisor and the group where he is inserted will help draw the lines of this textual body and, therefore, the student will be at ease to involve his physical body in his task. 
Bibliographical references

BARRÉ DE MINIAC, C. (2000). Le rapport à l'écriture : aspects théoriques et didatiques. Villeneuve d'Ascq (Nord): Presses Universitaires du Setentrion.

BARZOTTO, V. H. (2010). A expressão da modalidade linguística e a análise de textos acadêmicos. In: SILVA, C. L. C. R., CARLOS, J. T., PIRIS, E. L. (Eds.). Abordagens metodológicas em estudos discursivos (1 ed. pp. 27-35). São Paulo: Paulistana.

(2013) . Leitura, escrita e relação com o conhecimento. Faculdade de Educação, Universidade de São Paulo: Tese de Livre Docência.

CERTEAU, M. (1994). A invenção do cotidiano. Petrópolis: Vozes.

CHABANNE, J. C., BUCHETON, D. (2002) Parler et écrire pour penser, apprendre et se construire. L'écrit et l'oral réflexifs. Paris : PUF.

DESCHEPPER, C., THYRION, F. (2008). L'entrée dans le supérieur et l'accès aux discours universitaires : opérationnaliser la notion de rapport à l'écrit dans un projet de formation. In : CHARTRAND, S-G., BLASER, C. (Eds). Le rapport à l'écrit : un outil pour enseigner de l'école à l'université. (pp. 61-86). Namur, Belgique: Presses Universitaires de Namur.

FREUD, S. (1915). Os instintos e suas vicissitudes. In: Obras psicológicas completas de Sigmund Freud. (pp. 115-144, v. XIV) Ed. Standard Brasileira Rio de Janeiro: Imago (published in 1996).

LACAN, J. (1964). Le Séminaire, tome 11 : Les Quatre Concepts fondamentaux de la psychanalyse. Paris : Éditions du Seuil (published in 1973).

POTTIER, B. (1992). Sémantique générale. Paris : Presses Universitaires de France.

. (2000). Représentations mentales et catégorisations linguistiques. Louvain, Paris: Peeters.

RIOLFI, C. R. Formacriação. 1999. Available in: http://paje.fe.usp. $\mathrm{br} /$ geppep/textos/formacriacao.pdf

RIOLFI, C. R., ANDRADE, E. (2009). Ensinar a escrever o texto acadêmico: as múltiplas funções do orientador. Campinas, SP, Editora da Unicamp: Trabalhos em Linguística Aplicada. (pp. 98-118, v. 48). 
SPINELLI, D. (2012). Sem vela e sem choro: o desejo do analista e a formação do pesquisador In: RIOLFI, C., BARZOTTO, V. H. Sem choro nem vela. (pp. 35-48). São Paulo: Paulistana.

Claudia R. Riolfi

Enio Sugiyama Junior

Valdir H. Barzotto

\section{Resumen}

\section{CUERPO Y ESCRITURA: fuente y soporte de un estilo singular}

¿Porque los estudiantes universitarios tienden a transformar sus trabajos académicos en cortinas de humo para ocultar su singularidad? Para responder a esta cuestión, nosotros estudiamos manuscritos (con falta de originalidad, un exceso de cotizaciones o, incluso, un auto declaración de su propia incapacidad para escribir) de varias etapas de la elaboración escrita de un trabajo académico. Buscamos apoyarnos en el psicoanálisis para entender la correlación entre las transformaciones en el modo como cada estudiante maneja sus pulsiones con la posibilidad de construir huellas de autoría en su informe de investigación. Hicimos eso para leer el camino recorrido en dirección a la integración del cuerpo de dos estudiantes. Más específicamente, intentamos saber si hay una correlación entre una posición pasiva y una posición activa (que se obtiene a partir de una posición subjetiva) y una elaboración más bien hecha de las versiones. Concluimos que una persona puede manejar sus pulsiones más fácilmente cuando se permite obtener ayuda externa. Por esa razón, el orientador podría: a) Ayudar al su alumno a aceptar la separación de su imagen corporal relativamente consciente para ganar más "voces"; b) Actuar como un "secretario" de las diferentes voces, para ayudar al escritor a colocarlas en una jerarquía correcta; y c) Salir de escena cuando descubre que el alumno logró autonomía.

Palabras clave: escritura, estilo, psicoanálisis, cuerpo, autoría 